\title{
Impacts of macroalgal competition and parrotfish predation on the growth of a common bioeroding sponge
}

\author{
Manuel González-Rivero ${ }^{1,2, *}$, Renata Ferrari ${ }^{2}$, Christine H. L. Schönberg ${ }^{3}$, \\ Peter J. Mumby ${ }^{2,1}$ \\ ${ }^{1}$ College of Life and Environmental Sciences, University of Exeter, EX4 4PS, UK \\ ${ }^{2}$ Marine Spatial Ecology Laboratory, School of Biological Sciences \& ARC Centre of Excellence for Reef Studies, \\ University of Queensland, St. Lucia, Brisbane, Queensland 4072, Australia \\ ${ }^{3}$ Australian Institute of Marine Science, Oceans Institute at The University of Western Australia, 39 Fairway, Crawley, \\ Western Australia 6009, Australia
}

\begin{abstract}
Clionaids, an abundant group of bioeroding sponges, are important competitors of corals, but their interactions with other major taxa are poorly understood. This study examined the relative effect of predation and macroalgal competition on the growth of Cliona tenuis at Glover's Reef Atoll, Belize. A field experiment was designed to isolate the importance of each factor and its interactions, by means of exclusion cages to assess the effects of fish predators, and algal transplantation to assess the effects of macroalgal competition (Lobophora variegata), over $286 \mathrm{~d}$. To obtain complementary data on the net outcome of predation and competition in situ, predation intensity and the competitive effects on $C$. tenuis of 5 different competitors were monitored in the field. Competition with macroalgae significantly reduced the size of the sponge by $38 \pm 11 \%$ (SE). Despite a high predation rate $\left(1\right.$ bite $\left.100 \mathrm{~cm}^{-2} \mathrm{~h}^{-1}\right)$, no effect of the interaction of predation with macroalgal competition was detected. The in situ observations found that $L$. variegata was the strongest competitor limiting the growth of $C$. tenuis. Overgrowth of corals by clionaids and macroalgae continues to be a matter of concern, but our results suggest that the antagonistic competition between sponges and algae might weaken their potential combined effect on corals.
\end{abstract}

KEY WORDS: Porifera · Cliona tenuis · Lobophora variegata · Competition · Predation . Caribbean $\cdot$ Coral reefs

\section{INTRODUCTION}

Sponges are abundant and functionally important components of coral reef ecosystems (e.g. Díaz \& Rützler 2001) because they act in a number of processes that support ecosystem functions (Díaz \& Rützler 2001, Rützler 2004, Bell 2008). Bioerosion and competition are perhaps the most widely studied ways in which sponges contribute to the dynamics of coral reefs (Rützler 1975, López-Victoria et al. 2006, Bell 2008). Bioeroding sponges, mainly represented by clionaids and the genus $A k a$, are often the dominant internal borer organisms on shallow coral reefs (Rützler 1975, Sammarco et al. 1987, Glynn 1997), and can cause as much as $95 \%$ of the total internal bioerosion (Scoffin et al. 1980, Pari et al. 2002). Clionaid species can develop into large colonies spreading over several square metres (Rützler 2002, LopezVictoria \& Zea 2005). They are strong competitors for space, often overgrowing corals (Schönberg \& Wilkinson 2001, Rützler 2002, Chaves-Fonnegra \& Zea 2007). 
Given the interactions between excavating sponges and corals, and their great resistance to environmental stress (Rose \& Risk 1985, Vicente 1990b, Holmes 2000, Rützler 2002, Ward-Paige et al. 2005, Carballo 2006, Schönberg 2006), the ecosystem-level role of such sponges is expected to change as corals sustain greater levels of perturbation (Nyström et al. 2000, Rützler 2002, Ward-Paige et al. 2005): sponge abundance is expected to increase following coral reef disturbance (Ward-Paige et al. 2005, Schönberg \& Ortiz 2008). However, few studies have examined the response of Cliona to rapid coral mortality, which is one of the most striking outcomes of disturbance on reefs (Rützler 2002, Ward-Paige et al. 2005, Schönberg \& Ortiz 2008). Surprisingly, while increases in sponge density were found in the Florida reef tract, little change was found in the total cover of C. delitrix (Ward-Paige et al. 2005). This result implies that factors other than competition with living corals, such as competition with other taxa (i.e. algae), predation or sexual reproduction, may be constraining populations of Cliona on reefs.

To date, several studies have examined the role of predation (e.g. Dunlap \& Pawlik 1996, Wulff 1997 , Pawlik 1998, Pawlik et al. 2002, Wulff 2005) and competition (Vicente 1990a, Aerts \& van Soest 1997, Aerts 1998) on non-clionaid massive sponges. Predation appears to be a major driver of the distribution of non-excavating sponge species on reefs (Wulff 2005, 2006). However, little is known about the effect of predation on Cliona. Moreover, even though many excavating sponges are competitively superior to corals (Schönberg \& Wilkinson 2001, Rützler 2002, López-Victoria \& Zea 2004, López-Victoria et al. 2006), their interactions with other benthic taxa are little understood (López-Victoria et al. 2006). Studies undertaken in the temperate Mediterranean and on the Australian Great Barrier Reef have shown that macrophytes may reduce the growth of Cliona spp., although the individual competitor species were not identified (Cebrian \& Uriz 2006, Cebrian 2010). Similarly, monitoring of symbiotic clionaids in the Caribbean revealed that their growth can be reduced through competitive interactions with macrophytes, though, once again, the importance of individual competitors remains unclear (López-Victoria et al. 2006, Chaves-Fonnegra \& Zea 2011).
The present study investigated the effect of macroalgal competition and fish predation on the growth of a common excavating sponge in the Caribbean, Cliona tenuis Zea \& Weil, 2003. The study was comprised of 3 parts: (1) a factorial experiment to distinguish the effects and interaction of (a) competition by the common fleshy alga Lobophora variegata Lamouroux, 1809, and (b) fish predation on the growth of $C$. tenuis; (2) monitoring of in situ and nonmanipulated interactions between $C$. tenuis and other benthic taxa to compare Study 1 to the outcome of competition involving a wider range of (nonmanipulated) species; and (3) in situ estimates of predation intensity to better understand the composition of species involved and quantify the rate of the process.

\section{MATERIALS AND METHODS}

This study was conducted at Glover's Reef Atoll Marine Reserve, Belize (Fig. 1), located approximately $30 \mathrm{~km}$ off the Central American mainland and $15 \mathrm{~km}$ east from the Mesoamerican Barrier Reef. Studies were conducted between February and November 2009 ( 41 wk) on the windward side of Glovers Atoll on a Montastraea-dominated fringing reef $\left(16.753^{\circ} \mathrm{N}, 87.779^{\circ} \mathrm{W}\right)$.

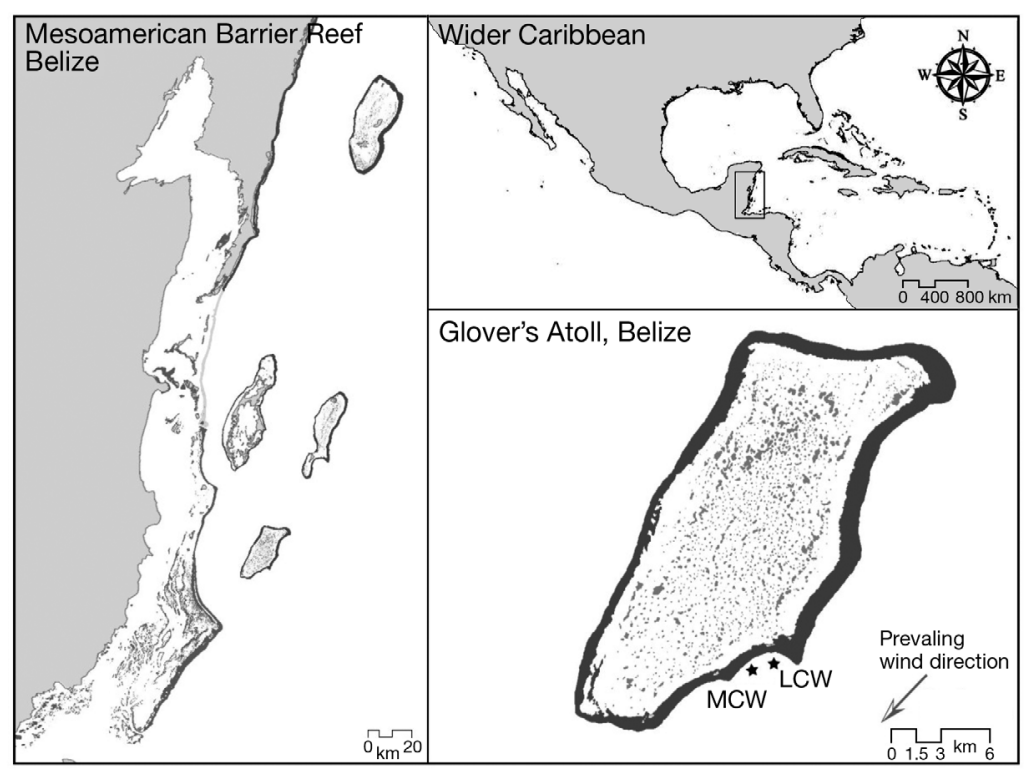

Fig. 1. Location of study site at Glover's Atoll in the Mesoamerican Barrier Reef (Belize), and the relative location of the atoll in the wider Caribbean region. Asterisks indicate study sites (MCW: Middle Caye Wall; LCW: Long Caye Wall. Source data: Global Self-consistent, Hierarchical, High-resolution Shoreline database (GSHHS) and Millennium Coral Reef Mapping project (MCRM) 


\section{Study 1: manipulation of predation and competition}

A total of 72 Cliona tenuis individuals were haphazardly chosen during SCUBA diving along a depth contour of $8 \mathrm{~m}$. The size of the sponges used in this study was $53 \pm 10 \mathrm{~cm}^{2}$ (mean $\pm \mathrm{SE}$ ), i.e. they had an approximate diameter of $8 \mathrm{~cm}$. All sponges were tagged and mapped to allow repeated measurements. Specimens were chosen in the field, based on the morphological descriptions for C. tenuis (Zea \& Weil 2003), and species identification was corroborated a posteriori in the laboratory, using a subsample of 10 sponges randomly chosen from previously tagged sponges. For these samples, tissue was digested in $70 \%$ nitric acid to obtain clean spicules, tylostyles and spirasters. Permanent spicule slides were prepared for microscopic examination and mounted on Araldite (Huntsman). Total length and axis width were measured in 15 randomly chosen spirasters per sample under a light microscope (1250x in immersion oil) using the Openlab software (Improvision 2008). Spicule measurements and the external morphology of individuals were compared to the published descriptions of the 3 common species of brown Caribbean Clionaidae (Zea \& Weil 2003), and our samples were identified as $C$. tenuis.

The effects of macroalgal competition and parrotfish predation on the growth of Cliona tenuis were tested using a fully orthogonal manipulative experiment over $286 \mathrm{~d}$. The macroalgal effect was carried out for one of the most abundant algal species, Lobophora variegata. Any pre-existing algal competition was eliminated by clearing a $10 \mathrm{~cm}$ belt around the periphery of all the sponges, using wire brushes. Polyvinyl chloride (PVC) exclusion cages of $40 \times 40 \times$ $50 \mathrm{~cm}$ and a $5 \mathrm{~cm}$ mesh width were used to control for the effects of predation and herbivory on algae. Cage controls had 2 lateral panels removed and were used to measure the potential cage effects of attenuated water flow and suppressed light on the sponge growth, while allowing fish predation. Given that C. tenuis maintain a symbiotic relationship with zooxanthellae (Granados et al. 2008), photosynthetically active radiation (PAR, 400 to $700 \mathrm{~nm}$ ) was measured to evaluate the extent of attenuation of a potential resource for the individuals under study. Measurements were carried out every 30 min during the experimental period inside and outside the cages using underwater PAR loggers (Dataflow Systems 2008). Individuals of $C$. tenuis were randomly allocated to 6 treatments listed in the following (Fig. 2).

Treatment 1 (T1): macroalgal competition $(n=12)$. Sponges were caged to control for the effect of predation on the sponge. Rubble pieces colonised by Lobophora variegata were positioned next to sponges such that algal fronds were in direct contact with approximately $75 \%$ of the perimeter of the sponge. Stainless steel and galvanised nails were driven into the dead coral substrate $10 \mathrm{~cm}$ from the sponge

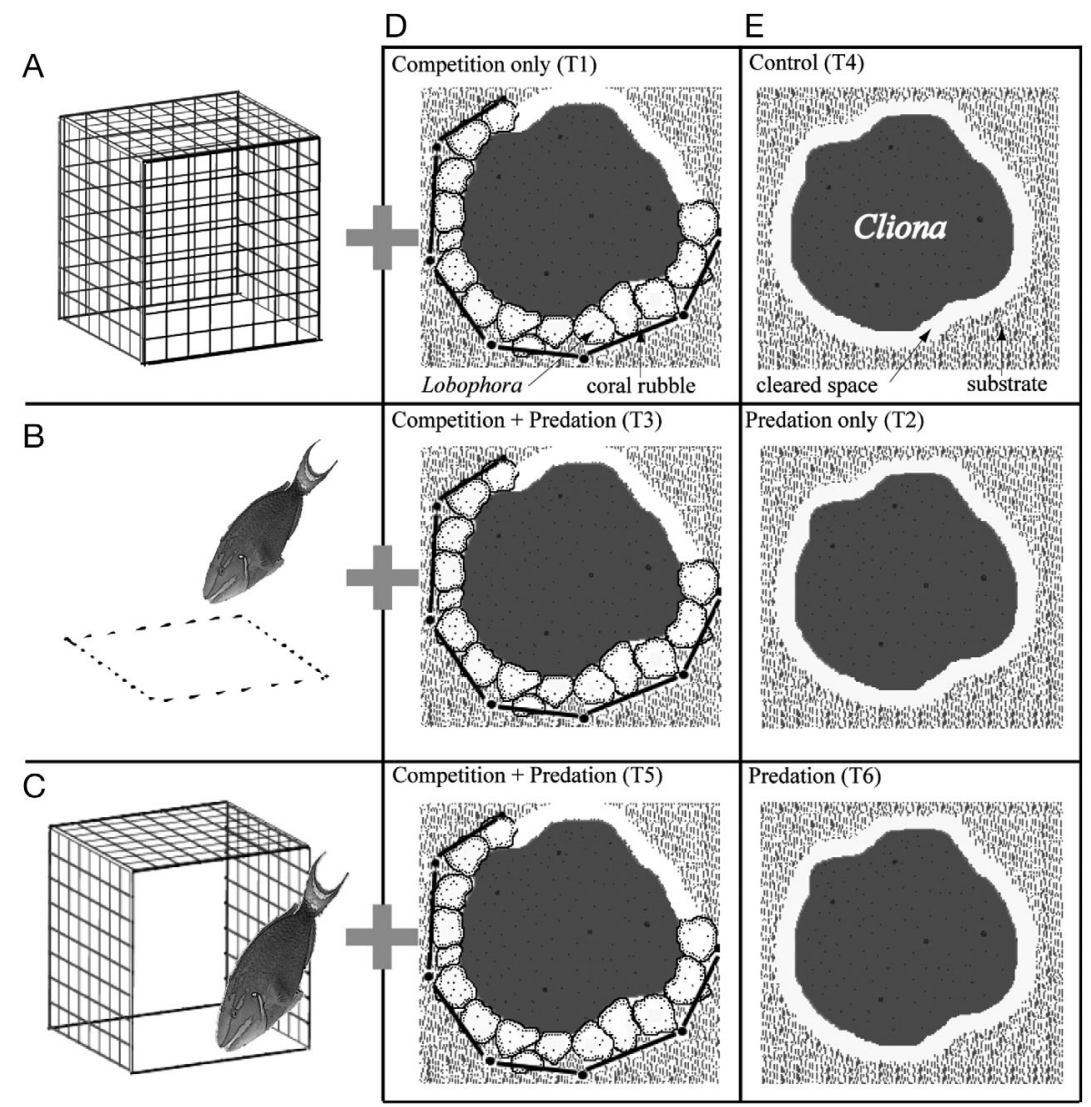

Fig. 2. Cliona tenuis. Schematic diagram of the experimental design to evaluate the effects of macroalgal competition and predation on growth of $C$. tenuis. Rows show the treatments (T) under predation exposure: (A) predation excluded (T1 and $\mathrm{T} 4 ; \mathrm{n}=12$ and 11, respectively), (B) predation exposed (T2 and T3; $\mathrm{n}=12$ and 13, respectively) and (C) predation exposed but simulating caging effects (T5 and $\mathrm{T} 6 ; \mathrm{n}=12$ ). Columns (D) and (E) show those treatments in which C. tenuis was in contact with Lobophora variegata (D: T1, T3 and T5; $\mathrm{n}=12,13$ and 12, respectively) or without algal competition (E: T2, T4, and T6; $\mathrm{n}=12,11$ and 12 , respectively) 
perimeter and used to affix the rubble pieces using cable ties.

Treatment 2 (T2): predation $(n=12)$. Sponges were uncaged and exposed to predators. Potential algal competitors were regularly cleared.

Treatment 3 (T3): combined effect of macroalgal competition and predation $(\mathbf{n}=13)$. To understand interactive effects of both stressors, Cliona tenuis was uncaged and maintained in contact with Lobophora variegata (as in T1).

Treatment 4 (T4): sponge growth in absence of predation and competition $(\mathbf{n}=\mathbf{1 1})$. Predation and competition effects were removed using cages and clearing each sponge periphery.

Treatments $5(\mathrm{~T} 5, \mathrm{n}=12)$ and $6(\mathrm{~T} 6, \mathrm{n}=12)$ : cage effects. These treatments involved testing for experimental artefacts on caged sponges due to potentially reduced light attenuation and water flow (Rosell \& Uriz 1992, Hill 1996, Schönberg 2006). Two treatments with partial cages were used: predation-only, no algal contact (T6) and the combined effect, predation and algal competition (T5). The caging effect was evaluated by comparing these treatments to the equivalent treatments that lacked cages, while both treatments allowed predators to feed on the sponge.

Maintenance of treatment conditions was performed every $3 \mathrm{wk}$; this included cleaning cages, replacing algae (when needed to keep the amount of competition constant) and clearing the sponge perimeter in the appropriate treatments. Sponges were filmed every 3 mo to determine sponge area, using the VidAna software (Hedley 2006). Photographic parallax error was avoided by using a frame of previously known area, which was placed in the same plane as the sponge. The depth of tissue penetration into the substrate for species of the Cliona viridis complex is limited to the first couple of centimetres, possibly due to the autotrophic association with zooxanthellae (Bergman 1983, Acker \& Risk 1985, Lopez-Victoria \& Zea 2005). Therefore, for this experiment, individuals of $C$. tenuis are considered to be sheets of constant thickness, independently of the experimental treatment, and growth is directly proportional to their lateral expansion and reported as the difference in size between the same individual at the beginning $(t=0 \mathrm{~d})$ and end of the experiment $(t=286 \mathrm{~d})$.

To assess the significance of competition and predation effects on sponge growth, a generalized least squares approach to a 2-factor analysis of covariance (ANCOVA GLS) was developed (restricted maximum likelihood method). The predicted variables included were predation (T2 and T4) and compe- tition (T1 and T4), as 2-level factors (presence/absence), which accounted for interactions (T3). Initial size of each individual (continuous) was included in the analysis as a covariate. The response variable used in the analysis was somatic growth $\left(\mathrm{cm}^{2}\right)$ after $286 \mathrm{~d}$, which was log transformed [ln(growth +100$)$ ] to satisfy assumptions. The variance of residuals was fitted to the model using a combination of the functions VarIdent, to account for heterogeneous variance within explanatory variables, and VarFixed, to account for the over-dispersion of residuals with the covariate (Pinheiro \& Bates 2000, Zuur et al. 2009).

Possible cage effects were also tested using 2 separate ANCOVA GLS analyses on comparable treatments under caged and partially caged conditions. For both analyses, initial size was included as a covariate. The response variable was the log-transformed growth after $286 \mathrm{~d}$. The first test compared the cage effect between treatments exposed to predation (uncaged: T2, partially caged: T6). The second test evaluated the effect between treatments exposed to the interaction of predation and competition (uncaged: T3 and partially caged: T5). For the second test, the model was fitted to include a variance structure allowing a heterogeneous variance of residuals within explanatory variables and correlated to the covariate, which was not needed for the first test. This variance structure was adjusted to the model using the VarIdent function (Pinheiro \& Bates 2000, Zuur et al. 2009). Homoscedasticity and normality of residuals in all analyses were tested graphically (McGuinness 2002, Zuur et al. 2009), and the graphs from the final models are shown in Supplement 1 at www.int-res.com/articles/suppl/m444p133_supp.pdf. Analyses were performed using $\mathrm{R}$, and the 'nlme' package (Pinheiro et al. 2009, R Development Core Team 2010).

\section{Study 2: unmanipulated interactions of Cliona tenuis with other competitors}

Interactions between Cliona tenuis and 5 common competitor categories were evaluated by measuring the linear advance of each competitor over time. A total of 113 sponges were randomly selected and tagged in January 2009. Competitor categories were: (1) coral $(\mathrm{n}=7)$, involving the species: Montastraea annularis, M. faveolata, Siderastrea siderea, Porites porites and Agaricia agaricites; (2) short algal turf (height $<10 \mathrm{~mm}$; $\mathrm{n}=44$ ); (3) tall algal turf (height $>10 \mathrm{~mm} ; \mathrm{n}=33$ ), which can trap sediment and forms a dense mat; (4) Dictyota 
pulchella $(\mathrm{n}=12)$; and (5) Lobophora variegata $(\mathrm{n}=13)$. The initial position of the sponge-competitor interface was tagged using a stainless steel and galvanised nail, and no collateral damage caused by tags was observed (Supplement 2 at www.int-res.com/articles/suppl/m444 p133_supp.pdf). Approximately every $90 \mathrm{~d}$, measurements of the distance from the nail to the edge of the interaction were taken using callipers $( \pm 0.01 \mathrm{~mm})$. As the growth of the sponge is not entirely symmetrical, the linear expansion was measured across an imaginary line directed to the centre of the sponge, and in a window of $1 \mathrm{~cm}$ of the perimeter of the sponge to minimise sampling errors. Positive values represent a linear advance of the sponge over the competitor, and negative values indicate sponge retraction. We present the final outcome of the interaction, as linear growth, after $286 \mathrm{~d}$ of evaluation, which we term 'linear advance'.

Competitive outcomes of sponge linear advance were evaluated by fitting a linear model using a GLS approach (estimation method: restricted maximum likelihood). The response variable was sponge linear advance, log transformed [ln('linear advance' + 100)], and the predictor variable was the species identity of each competitor (categorical, 5 levels). As withingroup heterogeneity of variance was observed, the structure of the variance was defined using the VarIdent function to allow for different standard deviations of residuals among competitors (Pinheiro \& Bates 2000, Zuur et al. 2009). Size and linear advance were not correlated (general linear model, $t$-statistic $=-0.569, \mathrm{df}=28, \mathrm{p}=0.574)$; therefore, size was not included in the analysis. For these tests, we employed the nlme package (v3.1) using the R software v2.13.0 (Pinheiro et al. 2009, R Development Core Team 2010). The model was evaluated using graphical methods (see Fig. S4 in Supplement 1 at www.intres.com/articles/suppl/m444p133_supp.pdf). Post-hoc comparisons among the effects of competitors on the linear advance were then evaluated using an Unequal N Tukey's honestly significant difference (HSD) test (STATISTICA software v6.0, StatSoft 2001).

\section{Study 3: predation levels}

Fish predation intensity was measured using static underwater video cameras placed between 1 and $2 \mathrm{~m}$ from the sponge, over periods of $1 \mathrm{~h}$. A total of $12 \mathrm{~h}$ of high definition footage was taken on 12 randomly selected sponges in November 2009. The approximate size of each evaluated sponge was $50 \mathrm{~cm}^{2}$. Fish species were identified from the footage, and the number of bites was counted for each individual. Data were pooled due to the low predation intensity, only considering those species that left bite marks on the sponge tissue, and therefore consumed the sponge. The species names of the fishes observed biting the sponge are given in the 'Results'. Predation intensity was estimated as the average number of bites per hour on each $100 \mathrm{~cm}^{2}$ of the sponge (bites $100 \mathrm{~cm}^{-2} \mathrm{~h}^{-1}$ ).

\section{RESULTS}

\section{Study 1: manipulation of predation and competition}

In the absence of competition by Lobophora variegata and predation by parrotfish, Cliona tenuis grew an average of $24.8 \pm 23.1 \mathrm{~cm}^{2}$ (mean $\pm 95 \% \mathrm{CI}$ ) after $286 \mathrm{~d}$, which was significantly dependent on the initial size (ANCOVA GLS; $\mathrm{df}=1,38 ; F=12.32$; $\mathrm{p}<$ 0.005 ; Table 1, Fig. 3). L. variegata was found to overgrow sponge tissue, which appeared transparent before necrosis. Nearly $12 \mathrm{~cm}^{2}$ of sponge colony $\left(11.98 \pm 11.2 \mathrm{~cm}^{2}\right.$; Fig. 3) was overgrown by L. variegata in 286 d (ANCOVA GLS; df $=1,38 ; F=5.34$; $\mathrm{p}<0.05 ;$ Table 1). Sponges exposed to predation did not change size when compared to control treatments (ANCOVA GLS; $\mathrm{df}=1,38 ; F=0.475 ; \mathrm{p}=0.495$; Table 1, Fig. 3). The combined effect of macroalgal competition and exposure to fishes did not interact significantly, and prevented sponge growth, causing a change in size of only $6.1 \pm 19.2 \mathrm{~cm}^{2}$ (mean $\pm 95 \% \mathrm{CI}_{i}$ ANCOVA GLS $; \mathrm{df}=1,38 ; F=0.602 ; \mathrm{p}=$

Table 1. Effects of macroalgal competition and fish predation on growth $(G)$ of Cliona tenuis, showing the summary outcome of a 2-factor ANCOVA generalised least squares analysis (GLS) using initial size as a covariate. The degrees of freedom (df), sum of squares (SS), F-statistic $(F)$ and the significance (p) of each factor are shown. Asterisks and bold mark those factors that showed a significant effect. Assumptions of the model were graphically evaluated and are shown in Fig. S1 in Supplement 1

\begin{tabular}{|lrccc|}
\hline Parameters & df & SS & $F$ & $p$ \\
\hline Competition (A) & 1 & 0.5078 & 5.3369 & $<\mathbf{0 . 0 5}{ }^{*}$ \\
Predation (P) & 1 & 0.0452 & 0.4749 & 0.495 \\
A:P interaction (AP) & 1 & 0.0573 & 0.6023 & 0.443 \\
Size (covariate) & 1 & 1.1730 & 12.323 & $<\mathbf{0 . 0 0 5}$ \\
A: Size & 1 & 0.0227 & 0.2385 & 0.628 \\
P: Size & 1 & 0.0278 & 0.2924 & 0.592 \\
A: P: Size & 1 & 0.0749 & 0.7873 & 0.381 \\
Residuals & 38 & 3.6615 & & \\
\hline
\end{tabular}




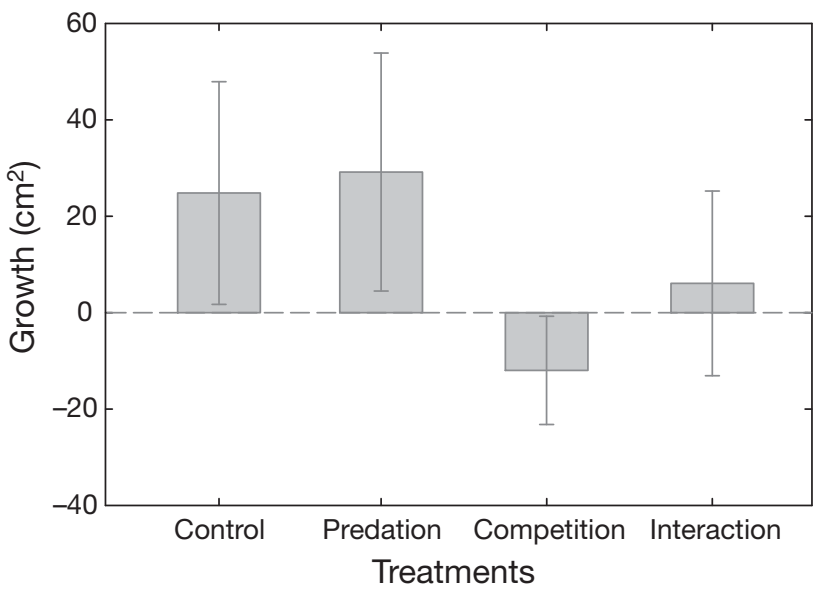

Fig. 3. Cliona tenuis. Average growth (area) under different treatment conditions after an experimental period of $286 \mathrm{~d}$. Vertical bars are the confidence intervals $(\alpha=0.05)$ of the respective means, and the dashed line shows null growth.

See Fig. 2 for a detailed description of the treatments

0.443; Table 1, Fig. 3). Most sponges exposed to predation received at least one bite mark in the period of $286 \mathrm{~d}$, but the recovery of scars was fast, being indistinguishable from the rest of the sponge after approximately 2 wk.

Cages significantly attenuated PAR by $18 \pm 2 \%$ (SE) of ambient levels (1-tailed paired $t$-test, $\mathrm{p}<$ 0.001). This light attenuation only weakly reduced the growth of Cliona tenuis and was only associated with non-significant differences between comparable partially caged and uncaged treatments (Fig. 4): predation (ANCOVA GLS; df $=1,17 ; F=0.661$; $\mathrm{p}=0.427$; Fig. 4A) and predation + competition (ANCOVA GLS; df $=1,18 ; F=$ 2.065; $\mathrm{p}=0.168$; Fig. 4B).

\section{Study 2: unmanipulated interactions of Cliona tenuis with other competitors}

On average, the growth of Cliona tenuis varied significantly among the competitor categories. The sponge was able to grow linearly over all except Lobophora variegata (GLS; df $=4,104$; $F=24.41 ; \mathrm{p}<0.0001)$. In the unmanipulated observations, Lobophora overgrew $C$. tenuis by $12.7 \pm 6.2 \mathrm{~mm}$ (mean $\pm 95 \%$ CI; Tukey's HSD; p $<0.05$; Fig. 5). Short turf offered the least resistance and was overgrown by $C$. tenuis at a linear advance of $26.7 \pm 5.2 \mathrm{~mm}$ (mean $\pm 95 \%$ CI; Tukey's HSD; p < 0.05; Fig. 5), followed by corals, which did not significantly differ from short turf (Table 2). The other 2 competitors significantly reduced the linear advance of $C$. tenuis, but their relative impacts did not differ significantly from one another (see Table 2 for details).

\section{Study 3: predation levels}

Parrotfish were the most frequent predators observed biting Cliona tenuis. Although the data were pooled because of the low number of observations per species of fish, the following species were involved, from the most to the fewest bites: the parrotfish Scarus iserti, Scarus coelestinus and Sparisoma viride, the damselfish Stegastes planifrons and Stegastes partitus, and the surgeonfish Acanthurus coeruleus. Sparisoma viride and Scarus coelestinus bit more intensively and left obvious marks on C. tenuis compared to the other fishes (Scarus iserti, Stegastes planifrons, Stegastes partitus, and A. Coeruleus), which left no visible impact of predation. The latter species were therefore excluded from the analysis, assuming that their activities did not significantly damage the sponge. Using the remaining 2 parrotfish species, the average predation intensity per sponge recorded was: $1.0 \pm 0.6$ bites $100 \mathrm{~cm}^{-2} \mathrm{~h}^{-1}$ $($ mean $\pm \mathrm{SE})$.
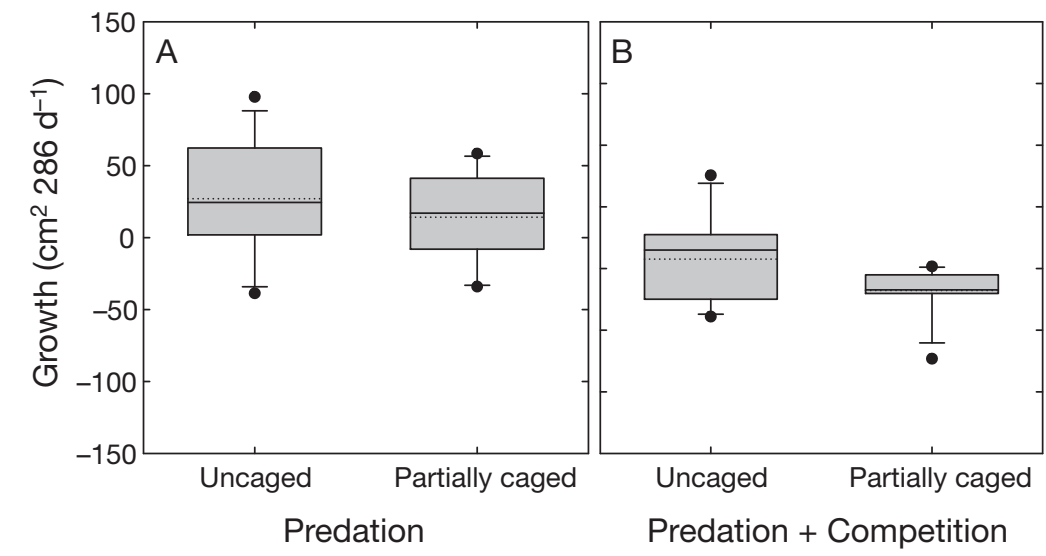

Fig. 4. Cliona tenuis. Caging effects on sponge growth subjected to similar treatments, but exposed (partially caged) or not (uncaged) to cage effect over a period of $286 \mathrm{~d}$. (A) Only predation effects (Treatment [T] 2 vs. T6), and (B) combined effect of algal competition and predation (T3 vs. T5). No significant caging effect was observed in either of these comparisons (see 'Results'). The box plot compares the growth of sponges in treatments without caging influence (cage control) versus uncaged treatments. Data points outside the range of the 5th and 95th confidence intervals (bars) are represented by dots, and the boxes indicate the inter-quartile range. The solid line inside the box represents the median; the dotted line represents the mean. See Fig. 2 for a detailed description of the treatments and sample sizes 


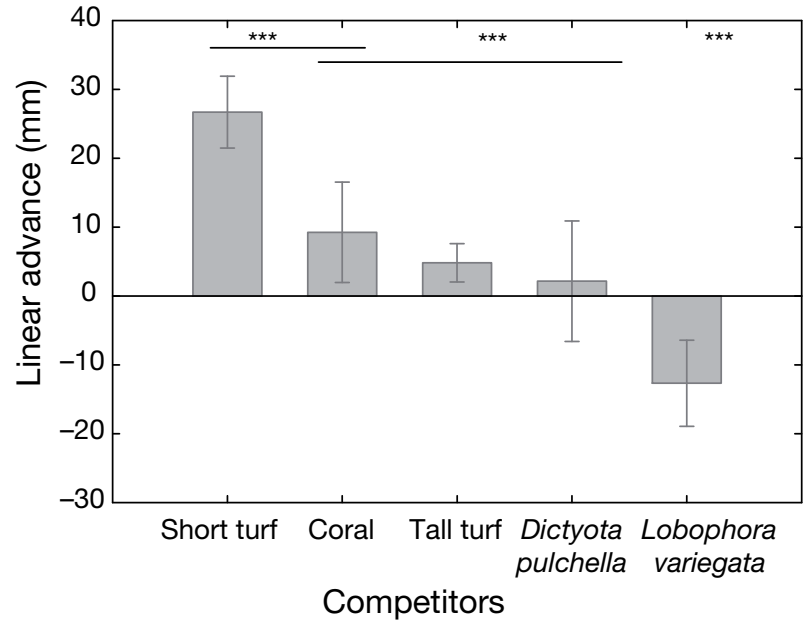

Fig. 5. Cliona tenuis. Linear growth of $C$. tenuis neighbouring common competitors over $286 \mathrm{~d}$. Vertical bars show the confidence intervals $(\alpha=0.05)$. Significant differences were observed in sponge growth according to the species in competition. Horizontal bars group the categories which did not show significant differences. Asterisks indicate the categories where significant differences $(p<0.05)$ were found using Unequal N Tukey's honestly significant difference (HSD) test for post-hoc comparisons. See Table 2 for details

Table 2. Effects of the interaction with other competitors on the linear advance of the sponge after $286 \mathrm{~d}$. The effect was evaluated fitting a GLS model. The identity of competitors was included as the predictive variable to explain changes in the linear advance of the sponge $\left(\mathrm{GLS}_{\mathrm{d}} \mathrm{df}=4,104 ; \mathrm{SS}=\right.$ $45.823 ; F=24.41 ; \mathrm{p}<0.0001)$. The table shows the outcome of the Unequal N Tukey's HSD test (error: between MS = 0.41606 , df =104), which includes the p-values of the pairwise comparisons among competitors. Significant effects are given in bold. Assumptions of the model were graphically evaluated and are shown in Fig. S3 in Supplement 1

\begin{tabular}{|lccccc|}
\hline Parameters & $\begin{array}{c}\text { Short } \\
\text { turf }\end{array}$ & Coral & $\begin{array}{c}D . \\
\text { pulchella }\end{array}$ & $\begin{array}{c}\text { Tall } \\
\text { turf }\end{array}$ & $\begin{array}{c}\text { L. varie- } \\
\text { gata }\end{array}$ \\
\hline Short turf & 0.159 & $\mathbf{< 0 . 0 0 1}$ & $\mathbf{< 0 . 0 0 1}$ & $<\mathbf{0 . 0 0 1}$ \\
Coral & & 0.828 & 0.972 & $<\mathbf{0 . 0 5 0}$ \\
Dictyota pulchella & & & 0.978 & $<\mathbf{0 . 0 5 0}$ \\
Tall turf & & & & $<\mathbf{0 . 0 0 5}$ \\
Lobophora variegata & & & & \\
& & & & \\
\hline
\end{tabular}

\section{DISCUSSION}

Cliona tenuis and closely related species have been found to be important competitors for space (Schönberg \& Wilkinson 2001, Rützler 2002, LópezVictoria et al. 2006), being some of the fastest growing species among congeners (López-Victoria et al. 2006). However, the factors controlling the growth of C. tenuis populations after coral decline are unclear. Our study reveals that macroalgal competition can significantly compromise the growth of individual sponges, while the effects of predation on growth appear to be undetectable. This conclusion adds to an emerging view that sponges and algae compete (Cebrian \& Uriz 2006, López-Victoria et al. 2006, Chaves-Fonnegra \& Zea 2011), but also highlights the species-specific nature of such interactions. Here, the encrusting macroalga Lobophora variegata is shown to be the strongest competitor. Indeed, $L$. variegata appears to be an important competitor, most notably with corals (i.e. de Ruyter van Steveninck et al. 1988, Nugues \& Bak 2006, Box \& Mumby 2007, Foster et al. 2008, Diaz-Pulido et al. 2010).

While Cliona tenuis was often observed to be competitively superior to other taxa, such as corals and macroalgae (except Lobophora variegata), competition still slowed down the lateral growth rate of the sponge. Previous studies have examined the mechanisms of sponge-coral interaction (López-Victoria et al. 2006, Chaves-Fonnegra \& Zea 2007, ChavesFonnegra et al. 2008) and found that clionaids can avoid the mechanisms of coral defence by undermining their polyps (López-Victoria et al. 2006, ChavesFonnegra \& Zea 2007). Although this is a physical interaction, polyp mortality might be achieved by chemical toxicity once the sponge is in contact with corals (Chaves-Fonnegra et al. 2008). In the case of confrontations between clionaids and macrophytes, however, much remains to be investigated.

Previous studies of coral-algal interactions might provide a framework for exploring algal-sponge interactions. These studies show that algae can affect their competitors through several mechanisms: (1) shading and asphyxiation, (2) compromising, by shading, the contribution of symbionts to the energy budget, (3) reducing access to food resources by compromising filtering/up-take efficiency, (4) allelopathic interaction and (5) mechanical abrasion, where allelopathy and shading effects can play a large role (see McCook et al. 2001). Among the algal species, Lobophora variegata and Dictyota bartayresiana were shown to be strongly allelopathic when interacting with corals, causing bleaching and mortality of the coral tissue when they are in contact with the algae (Rasher \& Hay 2010). Shading was also implicated as a major cause of stunted coral growth during interactions with macroalgae, in particular with $L$. variegata, because of its morphological structure (Box \& Mumby 2007).

The above-mentioned mechanisms of macroalgal competition will be of particular concern for the group of brown clionaids, as these are characterised by their symbiotic association with zooxantellae 
(Granados et al. 2008), and the lack of light has been shown to reduce the growth rate of symbiotic clionaids when they are shaded to $3-5 \%$ of ambient levels (Hill 1996, Schönberg 2001). This suggests that the mechanisms by which Lobophora variegata is competitively superior to Cliona tenuis may be due to allelochemical interaction and/or its shading effects on the sponge. Similar mechanisms might apply to the interactions of the sponge with Dictyota spp. Other competitors, such as long turf, may compete by offering physical resistance to sponge expansion by trapping sediments and forming a thick mat acting as a barrier (see Purcell 2000, Birrell et al. 2005). Although the competition of $C$. tenuis over corals may itself rely on chemical components present in the sponge (Chaves-Fonnegra et al. 2008), allelochemical assays are needed to address the potential effects of algal toxic compounds on the sponge tissue or vice versa.

We found no direct effect of predation on the growth of Cliona tenuis, as observed in previous studies in other congeneric excavating sponges, C. varians and C. delitrix (Hill 1998, Chaves-Fonnegra \& Zea 2011). In contrast, studies on free-living or semi-cryptic sponges have clearly shown strong negative impacts of predation upon their growth and survival (i.e. Wulff 1997, Pawlik 1998, Loh \& Pawlik 2009), which suggests that predation is an important driver of the abundance and distribution of coral reef sponges, as is the case for fleshy species (Wulff 2005). Whether our observations arise as a result of relatively low predation rates or the conciliation of potential predation effects by exceptionally rapid healing of lesions of clionaids is not yet clear (see Guida 1976, ChavesFonnegra \& Zea 2011). On the other hand, parrotfish have been identified as opportunistic predators of sponges in the Caribbean (Dunlap \& Pawlik 1996, Wulff 1997, Dunlap \& Pawlik 1998). Therefore, the limited impact of parrotfish on C. tenuis might simply reflect a relatively low preference for such sponges, possibly because of low palatability, low abundance, or a relative paucity of the convex surfaces that parrotfish prefer to feed on. It should be noted that a low abundance of predators is unlikely to be a factor in our study because parrotfish biomass at our study site is among the highest levels in the Caribbean (Mumby 2006). We also point out that while fish predation might not strongly influence the dynamics of adult $C$. tenuis in our study, predation might be a more important problem at other stages of ontogeny, such as the recruit and juvenile stages.

Although predation did not interact with macroalgal competition, a positive growth of sponges under the interaction treatment (Treatment 3) was observed.
This can be explained by the effects of herbivory on the transplanted algae, which may compromise the rate of advance of Lobophora variegata even when the proportion of competition was maintained constant over the experimental time, as well as during the observational study (Study 2). Therefore, the growth rate of sponge may be expected to change along with changes in grazing intensity, thus highlighting the importance of herbivory in mediating interactions among major benthic components of coral reefs (Coyer et al. 1993, Cebrian \& Uriz 2006, Calderon et al. 2007, Mumby et al. 2007). Further, rapid increase of the encrusting sponge Condrilla nucula after postbleaching coral mortality in Belize might be explained by the depletion of macroalgal competition in an overgrazed system (Aronson et al. 2002).

A more complete understanding of the roles of herbivory, competition and predation on the dynamics of clionaids requires expansion to include a wider range of body sizes and other demographic processes, such as fecundity and survival, as well as seasonal changes in the intensity of these interactions, given the phenology of clionaids. In addition, while competition can mediate vital rates of benthic invertebrates, the role of other attributes, such as the physical environmental or alternative interaction pathways among benthic individuals, such as food resource leaking, should also be considered (Preciado \& Maldonado 2005, van Duyl et al. 2011). With such information, individual-based observations of ecological processes can be scaled up to estimate responses at the population scale. Recent theoretical explorations of the competitive traits among sponges, corals and macroalgae have shown that competitive abilities, and the reduced herbivory due to increased predation of excavating sponges are relevant for predicting the trajectory of the ecosystem into alternative stable states (González-Rivero et al. 2011). Further, with concerns rising about the future of reef accretion (Hoegh-Guldberg et al. 2007), achieving greater predictive power for the response of bioeroding sponges to changes in community structure is becoming increasingly urgent.

Acknowledgements. This study was funded by the Fondo Nacional de Ciencia, Tecnología e Innovación (FONACIT) of Venezuela through a MGR PhD studentship, and the Wildlife Conservation Society (WCS), the Khaled bin Sultan Living Oceans Foundation (LOF) through a fellowship to R.F., the Natural Environment Research Council, and an ARC Laureate Fellowship to P.J.M. We are grateful to the WCS Belize staff and volunteers for their generous assistance during the course of the fieldwork, I. Chollett, J. Bilewitch and A. Marshell who kindly commented on the manuscript, and S. Bejarano for her collaboration on Fig. 2. 


\section{LITERATURE CITED}

Acker KL, Risk MJ (1985) Substrate destruction and sediment production by the boring sponge Cliona caribbaea on Grand-Cayman Island. J Sediment Petrol 55:705-711

Aerts LAM (1998) Sponge/coral interactions in Caribbean reefs: analysis of overgrowth patterns in relation to species identity and cover. Mar Ecol Prog Ser 175: 241-249

Aerts LAM, van Soest RWM (1997) Quantification of sponge/coral interactions in a physically stressed reef community, NE Colombia. Mar Ecol Prog Ser 148:125-134

- Aronson R, Precht W, Toscano M, Koltes K (2002) The 1998 bleaching event and its aftermath on a coral reef in Belize. Mar Biol 141:435-447

Bell JJ (2008) The functional roles of marine sponges. Estuar Coast Shelf Sci 79:341-353

Bergman K (1983) Distribution and ecological significance of the boring sponge Cliona viridis on the Great Barrier Reef, Australia. MSc thesis, McMaster University, Hamilton

Birrell CL, McCook LJ, Willis BL (2005) Effects of algal turfs and sediment on coral settlement. Mar Pollut Bull 51: 408-414

> Box SJ, Mumby PJ (2007) Effect of macroalgal competition on growth and survival of juvenile Caribbean corals. Mar Ecol Prog Ser 342:139-149

Calderon EN, Zilberberg C, de Pavia PC (2007) The possible role of Echinometra lucunter (Echinodermata: Echinoidea) in the local distribution of Darwinella sp. (Porifera: Dendroceratida) in Arraial do Cabo, Rio de Janerio State, Brazil. In: Custódio MR, Lobo-Hajdu E, Muricy G (eds) Porifera research: biodiversity, innovation and sustainability. Série Livros 28. Museu Nacional, Rio de Janeiro

- Carballo JL (2006) Effect of natural sedimentation on the structure of tropical rocky sponge assemblages. Ecoscience 13:119-130

Cebrian E (2010) Grazing on coral reefs facilitates growth of the excavating sponge Cliona orientalis (Clionaidae, Hadromerida). Mar Ecol 31:533-538

Cebrian E, Uriz MJ (2006) Grazing on fleshy seaweeds by sea urchins facilitates sponge Cliona viridis growth. Mar Ecol Prog Ser 323:83-89

Chaves-Fonnegra A, Zea S (2007) Observations on reef coral undermining by the Caribbean excaving sponge Cliona delitrix (Demospongiae, Hadromerida). In: Custódio MR, Lobo-Hajdu E, Muricy G (eds) Porifera research: biodiversity, innovation and sustainability. Série Livros 28. Museu Nacional, Rio de Janeiro

Chaves-Fonnegra A, Zea S (2011) Coral colonization by the encrusting excavating Caribbean sponge Cliona delitrix. Mar Ecol 32:162-173

Chaves-Fonnegra A, Castellanos L, Zea S, Duque C, Rodríguez J, Jiménez C (2008) Clionapyrrolidine A-a metabolite from the encrusting and excavating sponge Cliona tenuis that kills coral tissue upon contact. J Chem Ecol 34:1565-1574

Coyer JA, Ambrose RF, Engle JM, Carroll JC (1993) Interactions between corals and algae on a temperate zone rocky reef: mediation by sea urchins. J Exp Mar Biol Ecol 167:21-37

Dataflow Systems PL (2008) Odyssey photosynthetic irradiance recording system. Dataflow Systems PTY, Christchurch de Ruyter van Steveninck ED, Van Mulekom LL, Breeman AM (1988) Growth-inhibition of Lobophora variegata (Lamouroux) Womersley by scleractinian corals. J Exp Mar Biol Ecol 115:169-178

Díaz MC, Rützler K (2001) Sponges: an essential component of Caribbean coral reefs. Bull Mar Sci 69:535-546

> Diaz-Pulido G, Harii S, McCook LJ, Hoegh-Guldberg O (2010) The impact of benthic algae on the settlement of a reef-building coral. Coral Reefs 29:203-208

$>$ Dunlap M, Pawlik JR (1996) Video monitored predation by Caribbean reef fishes on an array of mangrove and reef sponges. Mar Biol 126:117-123

Dunlap M, Pawlik JR (1998) Spongivory by parrotfish in Florida mangrove and reef habitats. Mar Ecol 19: 325-337

Foster NL, Box SJ, Mumby PJ (2008) Competitive effects of macroalgae on the fecundity of the reef-building coral Montastraea annularis. Mar Ecol Prog Ser 367:143-152

Glynn PW (1997) Bioerosion and coral-reef growth: a dynamic balance. In: Birkeland C (ed) Life and death of coral reefs. Chapman and Hall, New York, NY

González-Rivero M, Yakob L, Mumby PJ (2011) The role of sponge competition on coral reef alternative steady states. Ecol Modell 222:1847-1853

- Granados C, Camargo C, Zea S, Sánchez JA (2008) Phylogenetic relationships among zooxanthellae (Symbiodinium) associated to excavating sponges (Cliona spp.) reveal an unexpected lineage in the Caribbean. Mol Phylogenet Evol 49:554-560

Guida VG (1976) Sponge predation in the oyster reef community as demonstrated with Cliona celata Grant. J Exp Mar Biol Ecol 25:109-122

Hedley J (2006) VidAna. Marine Spatial Ecology Lab, University of Exeter. www.marinespatialecologylab.org/ resources/vidana/

Hill MS (1996) Symbiotic zooxanthellae enhance boring and growth rates of the tropical sponge Anthosigmella varians forma varians. Mar Biol 125:649-654

Hill MS (1998) Spongivory on Caribbean reefs releases corals from competition with sponges. Oecologia 117: 143-150

Hoegh-Guldberg O, Mumby PJ, Hooten AJ, Steneck RS and others (2007) Coral reefs under rapid climate change and ocean acidification. Science 318:1737-1742

> Holmes KE (2000) Effects of eutrophication on bioeroding sponge communities with the description of new West Indian sponges, Cliona spp. (Porifera: Hadromerida: Clionidae). Invertebr Biol 119:125-138

Improvision (2008) Openlab. PerkinElmer, Coventry

> Loh TL, Pawlik JR (2009) Bitten down to size: fish predation determines growth form of the Caribbean coral reef sponge Mycale laevis. J Exp Mar Biol Ecol 374:45-50

> López-Victoria M, Zea S (2004) Storm-mediated coral colonization by an excavating Caribbean sponge. Clim Res 26:251-256

Lopez-Victoria M, Zea S (2005) Current trends of space occupation by encrusting excavating sponges on Colombian coral reefs. Mar Ecol 26:33-41

López-Victoria M, Zea S, Weil E (2006) Competition for space between encrusting excavating Caribbean sponges and other coral reef organisms. Mar Ecol Prog Ser 312:113-121

> McCook L, Jompa J, Diaz-Pulido G (2001) Competition between corals and algae on coral reefs: a review of evidence and mechanisms. Coral Reefs 19:400-417 
McGuinness KA (2002) Of rowing boats, ocean liners and tests of the ANOVA homogeneity of variance assumption. Austral Ecol 27:681-688

Mumby PJ (2006) The impact of exploiting grazers (Scaridae) on the dynamics of Caribbean coral reefs. Ecol Appl 16:747-769

Mumby PJ, Hastings A, Edwards HJ (2007) Thresholds and the resilience of Caribbean coral reefs. Nature 450:98-101

> Nugues MM, Bak RPM (2006) Differential competitive abilities between Caribbean coral species and a brown alga: a year of experiments and a long-term perspective. Mar Ecol Prog Ser 315:75-86

- Nyström M, Folke C, Moberg F (2000) Coral reef disturbance and resilience in a human-dominated environment. Trends Ecol Evol 15:413-417

Pari N, Peyrot-Clausade M, Hutchings PA (2002) Bioerosion of experimental substrates on high islands and atoll lagoons (French Polynesia) during 5 years of exposure. J Exp Mar Biol Ecol 276:109-127

$>$ Pawlik JR (1998) Coral reef sponges: Do predatory fishes affect their distribution? Limnol Oceanogr 43:1396-1399

> Pawlik JR, McFall G, Zea S (2002) Does the odor from sponges of the genus Ircinia protect them from fish predators? J Chem Ecol 28:1103-1115

Pinheiro JC, Bates DM (2000) Mixed-effects models in Sand S-PLUS. Springer, New York, NY

Pinheiro J, Bates D, DebRoy S, Sarkar D, the R Core Team (2009) nlme: linear and nonlinear mixed effects models. $\mathrm{R}$ package version 3.1-96

Preciado I, Maldonado M (2005) Reassessing the spatial relationship between sponges and macroalgae in sublittoral rocky bottoms: a descriptive approach. Helgol Mar Res 59:141-150

Purcell SW (2000) Association of epilithic algae with sediment distribution on a windward reef in the northern Great Barrier Reef, Australia. Bull Mar Sci 66:199-214

R Development Core Team (2010) R: A language and environment for statistical computing. R Foundation for Statistical Computing, Vienna

Rasher DB, Hay ME (2010) Chemically rich seaweeds poison corals when not controlled by herbivores. Proc Natl Acad Sci USA 107:9683-9688

Rose CS, Risk MJ (1985) Increase in Cliona delitrix infestation on Montastraea cavernosa heads on a organically polluted portion of the Grand Cayman fringing reef. Mar Ecol 6:345-363

Rosell D, Uriz MJ (1992) Do associated zooxanthellae and the nature of the substratum affect survival, attachment and growth of Cliona viridis (Porifera, Hadreomerida)? An experimental approach. Mar Biol 114:503-507

Rützler K (1975) The role of burrowing sponges in bioerosion. Oecologia 19:203-216

Rützler K (2002) Impact of crustose clionid sponges on Caribbean reef corals. Act Geol Hisp 37:61-72

Rützler K (2004) Sponges on coral reefs: a community

Editorial responsibility: Peter Edmunds,

Northridge, California, USA shaped by competitive cooperation. Boll Mus Ist Univ Genova 68:85-148

Sammarco PW, Risk MJ, Rose C (1987) Effects of grazing and damselfish territoriality on internal bioerosion of dead corals: indirect effects. J Exp Mar Biol Ecol 112: 185-199

Schönberg CHL (2001) Estimating the extent of endolithic tissue of a Great Barrier Reef clionid sponge. Mar Biodiversity 31:29-39

Schönberg CHL (2006) Growth and erosion of the zooxanthellate Australian bioeroding sponge Cliona orientalis are enhanced in light. Proc 10th Int Coral Reef Symp, Okinawa 1:168-174

Schönberg CHL, Ortiz JC (2008) Is sponge bioerosion increasing? Proc 11th Int Coral Reef Symp, Ft. Lauderdale 1:527-530

Schönberg CHL, Wilkinson CR (2001) Induced colonization of corals by a clionid bioeroding sponge. Coral Reefs 20: 69-76

Scoffin TP, Stearn CW, Boucher D, Frydl P, Hawkins CM, Hunter IG, MacGeachy JK (1980) Calcium-carbonate budget of a fringing-reef on the west-coast of Barbados 2. Erosion, sediments and internal structure. Bull Mar Sci 30:475-508

van Duyl FC, Moodley L, Nieuwland G, van Ijzerloo L and others (2011) Coral cavity sponges depend on reefderived food resources: stable isotope and fatty acid constraints. Mar Biol 158:1653-1666

Vicente VP (1990a) Overgrowth activity by the encrusting sponge Chondrilla nucula on a coral reef in Puerto Rico. In: Rützler K (ed) New perspectives in sponge biology. Smithsonian Institution Press, Panama

- Vicente VP (1990b) Response of sponges with autotrophic endosymbionts during the coral-bleaching episode in Puerto Rico. Coral Reefs 8:199-202

> Ward-Paige CA, Risk MJ, Sherwood OA, Jaap WC (2005) Clionid sponge surveys on the Florida Reef Tract suggest land-based nutrient inputs. Mar Pollut Bull 51:570-579

Wulff JL (1997) Parrotfish predation on cryptic sponges of Caribbean coral reefs. Mar Biol 129:41-52

Wulff JL (2005) Trade-offs in resistance to competitors and predators, and their effects on the diversity of tropical marine sponges. J Anim Ecol 74:313-321

Wulff JL (2006) Sponge systematics by starfish: predators distinguish cryptic sympatric species of Caribbean fire sponges, Tedania ignis and Tedania klausi n. sp (Demospongiae, Poecilosclerida). Biol Bull (Woods Hole) 211: 83-94

Zea S, Weil E (2003) Taxonomy of the Caribbean excavating sponge species complex Cliona caribbaea-C. apricaC. langae (Porifera, Hadromerida, Clionaidae). Caribb J Sci 39:348-370

Zuur AF, Ieno EN, Walker NJ, Saveliev AA, Smith GM (2009) Mixed effects models and extensions in ecology with R. Springer, New York

Submitted: April 28, 2011; Accepted: September 26, 2011 Proofs received from author(s): December 16, 2011 